\author{
Anna Formica \\ Doctor, Researcher \\ Istituto di Analisi dei Sistemi ed Informatca “Antonio Ruberti” (IASI), National Research Council (CNR), \\ Rome, Italy \\ ORCID ID 0000-0002-7992-6898 \\ anna.formica@iasi.cnr.it \\ Alessia Barbagallo \\ Doctor, Postdoc \\ Istituto di Analisi dei Sistemi ed Informatca “Antonio Ruberti” (IASI), National Research Council (CNR), \\ Rome, Italy \\ alessia.barbagallo@iasi.cnr.it
}

\title{
INTEGRATING SEMANTIC SEARCH IN E-LEARNING TECHNOLOGIES: THE ELSE SYSTEM
}

\begin{abstract}
The integration of semantic web methodologies and e-learning technologies is a challenge that has attracted a lot of attention for a decade. Given this, the purpose of this paper is the definition of a new e-learning semantic web methodology for the development of courses for health professionals in both distance and residential learning modes. ELSE is an ontology-based system which allows the construction of customized e-learning courses according to the needs and learning preferences of the user. It integrates semantic search methodologies and e-learning technologies. The underlying methodology relies on a reference domain ontology and teaching multimedial interactive modules, referred to as Reusable Learning Objects (RLOs), which are annotated according to the concepts of the ontology. The user can specify his/her training needs by selecting a set of concepts from the ontology, and the SemSim semantic search engine allows the identification of the set of RLOs that satisfy the user request at best, in efficient way. SemSim is a semantic similarity method which has been extensively experimented with and shows a higher correlation with human judgment with respect to the most relevant similarity methods defined in the literature. The set of RLOs is successively reorganized according to the learning preferences of the user. ELSE has been developed within a project of the CME (Continuing Medical Education) program - ECM for Italian participants - whose goal is the introduction of new methodologies and tools to keep updated health professionals and, in particular, medical specialists, in order to ensure effectiveness, safety, and efficiency of the national health service.

ELSE has been tested and validated in the domain of osteoporosis, and the overall judgment about the system is very positive, both in terms of usability and effectiveness of customization. The system has been developed in cooperation with the ECM provider SPES S.c.p.A., accredited by the Italian Ministry of Health.
\end{abstract}

Keywords: E-learning; learning profile; reusable learning object; semantic search; domain ontology; semantic annotation.

\section{INTRODUCTION}

CME (Continuing Medical Education - ECM for Italian participants) is the process by which health professionals keep updated to meet the needs of patients, the health service, and their own professional development [1]. The goal of this paper is the presentation of ELSE (E-Learning for the Semantic ECM), which is an ontology-based system integrating semantic search methodologies and e-learning technologies [2] [3]. It aims at improving the access and the retrieval of resources in Learning Management System (LMS) repositories, in order to create customized e-learning courses. It has been developed within a project whose goal is the introduction of new methodologies and tools to keep health professionals updated within the ECM program. The goal of the ECM program is the updating of health professionals and, in particular, medical specialists, in order to ensure effectiveness, safety, and efficiency of the national health service (Italian Legislative Decree 229/99). The participation of the health 
professionals in the ECM program is measured according to credits. Thanks to the cooperation with the ECM provider SPES S.c.p.A. [4], which is accredited by the Italian Ministry of Health to develop courses for health professionals in both distance and residential learning modes, ELSE proposes a new e-learning semantic methodology for the acquisition of ECM credits. It allows the creation of customized semantic ECM e-learning courses by relying on the learning platform MOODLE [5].

The courses are customized because they are created according to the user needs and the specification of his/her learning preferences (learning profile). The approach proposed in ELSE is ontology-based, i.e., it relies on a reference ontology which is a shared conceptualization of the domain of interest $[6,7]$. The training material is selected by the domain experts and organized according to digital teaching multimedial and interactive modules referred to as Reusable Learning Objects (RLOs). The RLOs are then annotated according to the concepts of the ontology, in order to be searched and retrieved. The user can specify his/her training needs by selecting a set of concepts from the ontology, and the SemSim semantic search method [8,9] allows the selection of the RLOs that satisfy the user request at best, in efficient way. SemSim is a semantic similarity method which has been extensively experimented with, and has shown a higher correlation with human judgment with respect to the most representative similarity search methods defined in the literature [9, 10]. According to SemSim, a set of RLOs is selected, which is successively reorganized according to the learning profile of the user. ELSE can be accessed via the web, by logging into the ECM-SPES platform [4]. It has been tested in the osteoporosis domain, and the overall judgment about the system is very positive, both in terms of usability and effectiveness of customization.

This paper is an updated and revised version of [2], conceived for non-specialist readers due to the increasing interest of ontology-based approaches in e-learning [11]. After the Related Work, the ELSE methodology is presented. In particular, first the ontology-based approach is described and then the RLOs are illustrated. Successively, the learning profile of the user is addressed, by describing four different profiles that the user can choose. Then, the SemSim semantic search engine on which the methodology is based, is described. In Section 7, the architectural aspects and the implementation issues of the system are addressed, and in Section 8 the validation and the experimental results are described. The conclusion and future work follow.

\section{RELATED WORK}

The benefits and the potential contribution of ontologies to semantic e-learning solutions have been extensively addressed in [12], where they are considered an essential component of e-learning systems. Their use and the effectiveness in e-learning applications have been widely analyzed in the literature [11]. In [13], for instance, the authors state that "the domain ontology is an inevitable part of advanced learning solutions" as it (i) provides a backbone for the unification of the granularity of all kinds of learning objects, (ii) facilitates the interoperability and exchange of learning resources, (iii) allows clearer diagnostics of the student misunderstandings, and (iv) supports strategies for planning the adaptive behavior of the system which are domain independent.

In our approach, with respect to the various proposals integrating semantic technology in e-learning, as for instance $[14,15]$, the ontology consists of a tree which models the ISA relationships among the concepts of the application domain $[16,17]$. This simple structure of the ontology is not a weakness of the approach but is a strength because the tree is a prerequisite in order to efficiently search and retrieve the RLOs according to the semantic search method SemSim. In fact, as will be shown in the next sections, SemSim has a 
polynomial time complexity and, with respect to the logic programming techniques that are adopted in the mentioned papers, it is based on the information content approach [18].

\section{THE ONTOLOGY-BASED APPROACH}

ELSE is based on a domain ontology which allows the definition of the concepts, and their relationships, within the reference domain. The ontology building process is performed according to the UPON methodology, which is based on OPAL [19]. UPON, with the involvement of domain experts, allows the construction of a domain ontology starting from documentary resources. In the initial phase, tools for the automatic extraction of knowledge from unstructured documents are used. The ontology is successively constructed, incrementally, with the help of domain experts, who enrich, refine and validate the extracted knowledge.

In this paper the reference domain is osteoporosis. With regard to the automatic extraction of knowledge, the AlchemyApi tool has been used [20], which allows the extraction of the main keywords of content from HTML pages or text pages. Page contents are analyzed by using statistical algorithms and natural language processing techniques. Once the knowledge has been extracted, the UPON methodology allows the ontology construction according to the following five steps:

$\checkmark$ Lexicon: it is a set of terms (concepts) which are relevant to the domain; in the osteoporosis domain, they are, for instance, osteoblast, osteoclast, biphosphonate, bone cell, etc...

$\checkmark$ Glossary: it consists of the concept definitions; for instance: the osteoblast is a cell that processes the embryonic bone, etc...

$\checkmark$ OPAL categories: each concept of the lexicon is classified according to one of the three conceptual categories according to the OPAL methodology: Actors, i.e., entities playing an active role in any process (e.g., doctor, physiotherapist, etc...); Processes, i.e., entities representing transformations, procedures, and protocols, (e.g., bone turnover); Objects, that are passive entities on which both Actors and Processes operate (e.g., vertebra, femur, etc...)

$\checkmark$ Taxonomy: is the set of concepts organized according to a tree, by identifying the ISA relationships between concepts; for instance, osteoblast ISA bone cell, etc...

Note that in ELSE the ontology building phase is required in the case, for instance, the teachers realize that, in order to construct a course, the existing ontologies are not adequate, or sufficiently detailed.

In the osteoporosis domain, the automatic extraction according to AlchemyApi produced a lexicon of 1838 concepts. This set, once validated and refined by the domain experts, was reduced to 197 concepts. Successively, the glossary has been constructed by associating a definition with each of the 197 concepts defined in the lexicon. Each concept of the lexicon has been further categorized according to OPAL and, finally, 37 Processes and 160 Objects have been identified.

We would like to note that in our experiment Actors have not been considered due to the nature of the system conceived to create e-learning courses which are, of course, passive entities on which Processes operate. Furthermore, with regard to the definition of the ISA hierarchy, 37 further concepts have been introduced corresponding to the missing least upper bounds of the concepts, i.e., their less general common hyperonyms. In the case of postmenopausal osteoporosis and senile osteoporosis, for instance, the concept primary osteoporosis was introduced, which was not present in the ontology. At the end, we have defined an ontology about osteoporosis containing 234 concepts. 


\section{THE REUSABLE LEARNING OBJECTS}

As mentioned in the Introduction, the learning material is organized according to Reusable Learning Objects (RLOs). It has been previously selected by the domain experts, i.e., teachers, in order to identify the teaching modules of the courses. These are then digitalized to be elaborated by an e-learning system. Therefore, the RLOs are the digital representations of the teaching modules that have been identified by the domain experts.

In ELSE an RLO is a multimedial and interactive teaching unit which is associated with the following data:

$\checkmark$ type: the type of the material contained in the RLO, which can be: theory (T), exercise/practice $(\mathrm{P})$, example/case $(\mathrm{C})$, insight $(\mathrm{I})$;

$\checkmark$ semantic annotation: the set of the concepts selected from the reference ontology that describe the material contained in the RLO;

$\checkmark$ learning outcomes: the list of competencies or skills that the professionals are expected to achieve by learning the material contained in the RLO;

$\checkmark$ time: the time estimated by the teachers needed for professionals to complete the RLO.

With regard to the type, the following typologies have been identified: theory (T), exercise/practice (P), example/case (C), insight (I), according to the vocabulary provided by the POEM (Pedagogy Oriented Educational Metadata) model [21], and the Share.TEC model, developed within the European project E-Content Plus Share.TEC [22].

The semantic annotation is fundamental for the search and retrieval of the RLOs that have to be selected in order to create the courses. It is used by the semantic search engine SemSim that is illustrated in the following sections. A semantic annotation consists of a set of ontology concepts that describe the content of the RLO. In ELSE the semantic annotation is a semi-automatic activity that requires the supervision of the domain expert, who, in this case, is the teacher of the course. It is obtained in two steps: (i) extraction of the keywords from the RLO, and (ii) matching the keywords with the concepts of the ontology. In the ELSE system, the first step is performed according to natural language processing tools, see for instance [20], whereas the activity concerning the second step consists, in the easiest cases, in removing blank spaces, typos, upper/lowercase letters, or identifying synonyms etc.., and in the most difficult cases, in removing the keywords whose meaning does not match the concepts of the ontology. In the osteoporosis domain, an example of a semantic annotation of an RLO is: (primary osteoporosis, bone turnover, menopause, spinal fracture).

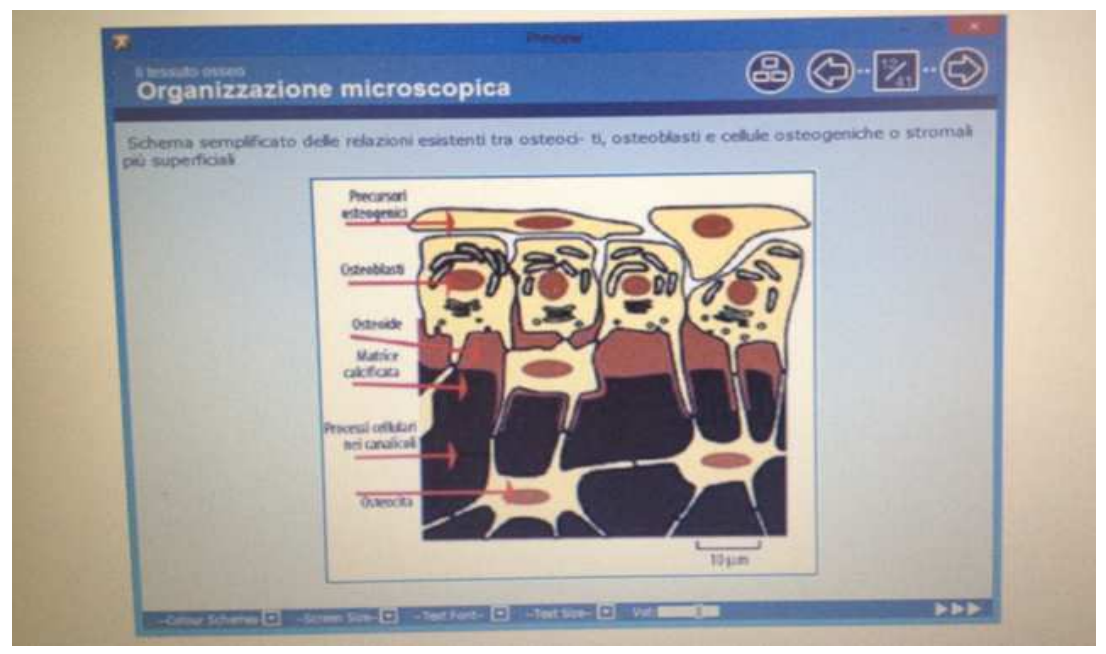

Fig. 1: A slide of an RLO showing the microscopic organization of bone cells 
Regarding the learning outcomes, we referred to the Tuning Project [23]. The goal of this project is to develop a common core of learning skills or competencies, for degree programs in Europe. They are statements about what a student is expected to know at the end of a learning process (e.g., ethical and legal principles in medical practice, prescription of drugs, psychological and social aspects of a patient's illness, etc ...).

The time depends on the complexity of the material contained in the RLO. However, in ELSE the RLOs have been fragmented in order to be completed in approximately 15-20 minutes. Figure 1 shows one of the slides of an RLO, where the microscopic organization of bone cells is described in Italian (the English version is under development).

\section{THE LEARNING PROFILE}

In our approach, the learning profile allows the creation of customized learning courses taking into account the learning preferences of the user. The learning preferences have been defined in line with the Felder-Silverman model [24]. This model, selected by the experts of SPES S.c.p.A. [4], has been accredited by the Italian Ministry of Health. It is considered as the most appropriate to develop courses for health professionals, in both distance and residential learning modes. In particular, the following four approaches have been identified: inductive vs deductive, and sequential vs global. Taking into account the possible combinations of these approaches, in ELSE the user can choose one among the following four different profiles:

$\checkmark$ Inductive/Sequential (IS): according to the IS approach, the user prefers to proceed by induction starting from examples, cases, and experiments in order to obtain principles and theories. Therefore, the theoretical elements are achieved starting from practical and concrete cases. The inductive process is performed gradually, as the teaching material is presented, going from the easiest to the most difficult concepts. Furthermore, in associating the inductive approach with the sequential one, the user prefers starting from the concrete cases, and sequentially addressing the related theoretical concepts, in an alternation of examples and the related theories. In Figure 2, the organization of the teaching material according to the IS profile is shown, where T, P, C, and I are the types of the RLOs.

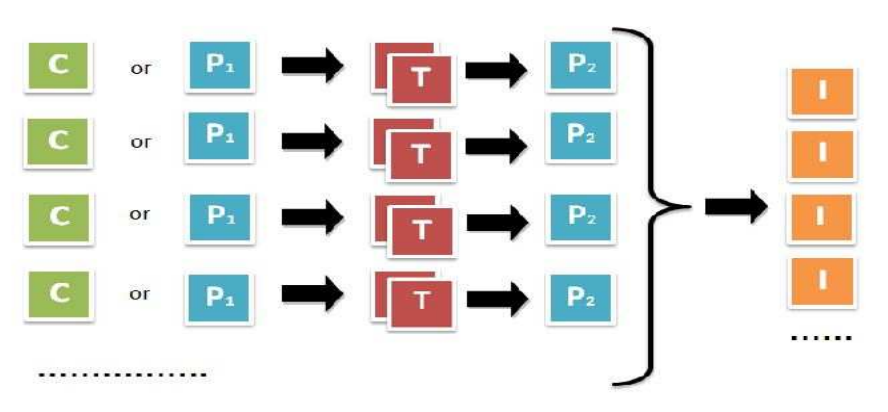

Fig. 2: Organization of the teaching material according to the IS learning profile

$\checkmark$ Inductive/Global (IG): similar to the IS user, the IG user achieves an understanding of principles and theories through the study and the analysis of cases, examples and experiments, sometimes supplemented by insights, as collections of data or images, etc... However, the specificity of this user is the comprehensive, non-sequential information because he/she prefers to learn by capturing an overview of the global situation. By associating the inductive approach with the global one, therefore, the user simultaneously 
addresses examples, cases, exercises, and problems related to different topics, in a nonsequential mode, in order to successively acquire the related principles and theories through personalized paths. Similar to the previous case, in Figure 3 the organization of the teaching material according to the IG profile is shown.

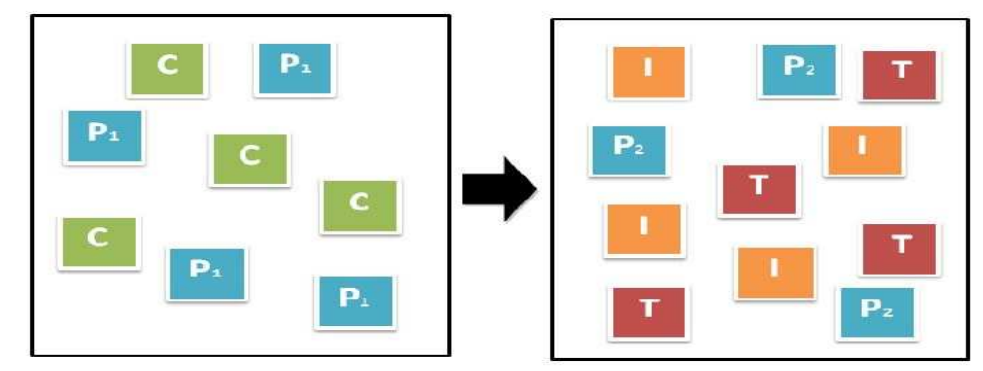

Fig. 3: Organization of the teaching material according to the IG learning profile

$\checkmark$ Deductive/Sequential (DS): according to the DS approach, the user prefers to proceed by inference, starting from a general theory to derive conclusions about specific cases. Thanks to the sequential approach, the deduction is linear in the sense that, starting from simpler concepts, complex concepts are then achieved. Therefore, the association of the deductive approach with the sequential one requires that theoretical elements be sequentially interspersed from examples, cases and practical experiments, as well as all the material for completing the course. In Figure 4, a representation of the teaching material organized according to the DS profile is given.

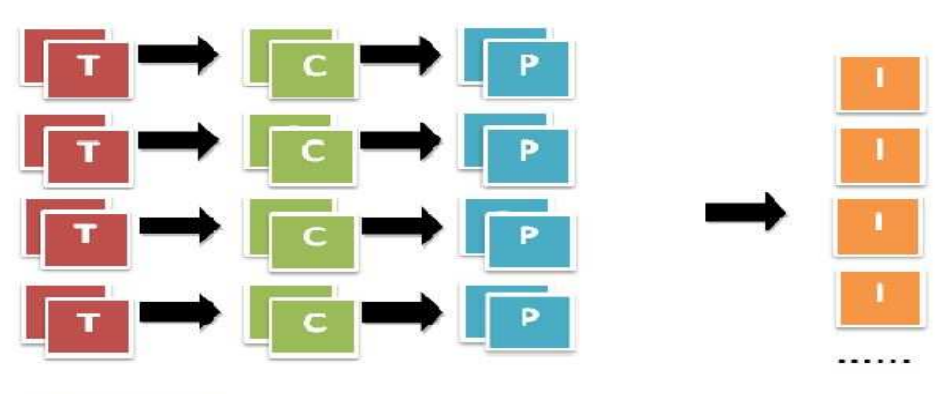

Fig. 4: Organization of the teaching material according to the DS learning profile

$\checkmark$ Deductive/Global (DG): similar to the DS user, the DG user analyzes the information starting from general, theoretical principles in order to achieve specific and concrete cases. In combining it with the global approach, the information is provided in a non-sequential way. Therefore, in the association of the deductive approach with the global one, the user faces at the same time, and in a non-sequential way, different theoretical elements in order to achieve an overview of the problem, and then tackles exercises, cases, examples, in order to contextualize the overall framework. Figure 5 shows the organization of the teaching material according to the DG profile. 


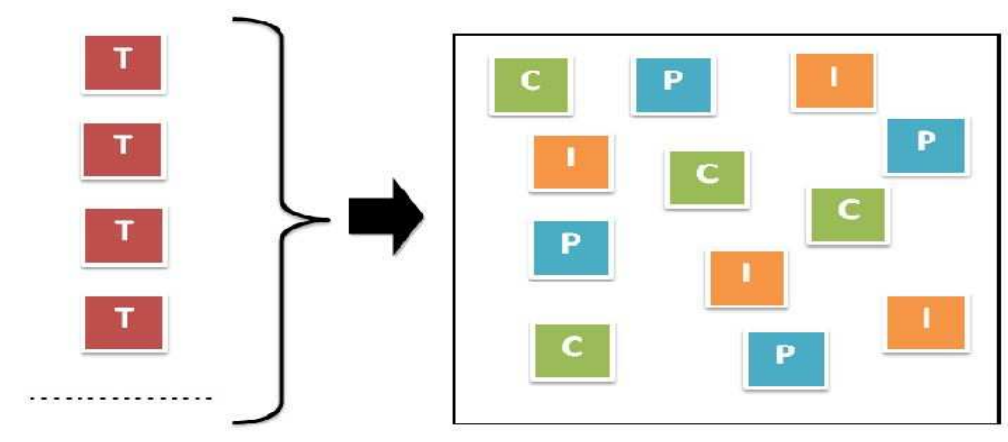

Fig. 5: Organization of the teaching material according to the DG learning profile

\section{THE SEMANTIC SEARCH APPROACH}

After the creation of the learning profile, the user has to specify his/her specific training needs in order to create the customized course. The user can select a set of concepts from the reference ontology in order to specify the training needs. This set represents the user request that has to be matched with the learning material contained in the repository of the ECMSPES provider, i.e., the RLOs. The match is performed by the semantic search engine SemSim [9], on the basis of the semantic annotations of the RLOs and the learning profile of the user described above. SemSim, in particular, allows the search and the retrieval of the available RLOs by comparing the user request with the semantic annotations of the RLOs (which are also sets of concepts) as shown in this section. The retrieved RLOs, which can be of type T, P, C, and I, are then organized taking into account the learning profile of the user.

SemSim is a semantic similarity search method based on the information content approach defined by Lin [18], which has been extensively investigated in the literature. It requires that the taxonomy (ontology) is a weighted ISA hierarchy, i.e., a ISA hierarchy whose concepts are weighted. Let $w(c)$ be the weight associated with a concept $c$ of the ontology. On the basis of the standard argumentation of information theory, the information content of $c$ is defined as $-\log w(c)$. We assume that the ontology is a tree, therefore the least upper bound $(l u b)$ of any pair of concepts is defined and provides the maximum information content shared by the pair of concepts in the taxonomy. Therefore, given two concepts $c i$, and $c j$ of the ontology, their similarity, referred to as consim $(c i, c j)$, is defined as the maximum information content shared by the concepts divided by the sum of their information contents:

$$
\operatorname{consim}(\operatorname{ci}, c j)=2 \log w(\operatorname{lub}(c i, c j)) /(\log w(c i)+\log w(c j))
$$

The evaluation of the similarity between the user request and the semantic annotation of an RLO is based on the consim similarity, taking into account that the semantic annotation is a set of concepts of the ontology as well. The user request and the semantic annotation are compared by evaluating the consim for each pair of concepts in the sets. However, we are not interested in all possible pairs because in many cases the comparison is meaningless (e.g., contrasting osteoblast vs necrosis factor), therefore SemSim restricts the analysis to the pairs that exhibit high affinity. The exclusive match philosophy is adopted in particular, where the elements of each pair of concepts do not participate in any other pair [10]. Assume for instance that we have a set of boys and a set of girls, all possible sets of marriages are considered, when polygamy is not allowed. Semantic similarity is computed by making use of 
the Hungarian algorithm, which solves the maximum weighted matching problem in bipartite graphs in polynomial time.

We have experimented with SemSim in different application domains within European Projects, and it shows a higher correlation with human judgment with respect to the most representative proposals defined in the literature [9].

\section{THE ELSE SYSTEM}

ELSE can be accessed via the web by logging into the ECM-SPES learning platform [4]. In this section, the architecture and the implementation of the system are presented.

ELSE is a web-based system, with a three-tier architecture: the web interface, the application server, and the database server. The communication protocol among the levels is TCP/IP. The ELSE logical architecture is shown in Figure 6. At application level, we have the following modules: the User Profile Manager, the Semantic Content Searcher, the Course Designer, the Course Manager, and the Learning Management System (LMS) Adapter, which are shown below. At persistence level, ELSE contains the repositories about the enriched User Profiles, the Ontologies, and the Semantic Annotations of the RLOs. The RLOs are stored in the ECM-SPES platform, which also contains the repository of the data about the information of the users.

In order to access the ELSE system, users have to be previously registered on the ECMSPES platform. The module devoted to the interactions with the ECM-SPES Learning Management System is the LMS Adapter. Their communication concerns the user authentication, the acquisition of the data about the user and the related courses, and the export of the courses. The User Profile Manager interacts with the LMS Adapter for the acquisition of the user information from the ECM-SPES provider. These data are stored in the User Profiles repository, where also the user learning preferences and the list of the courses that have been completed by the user are contained.

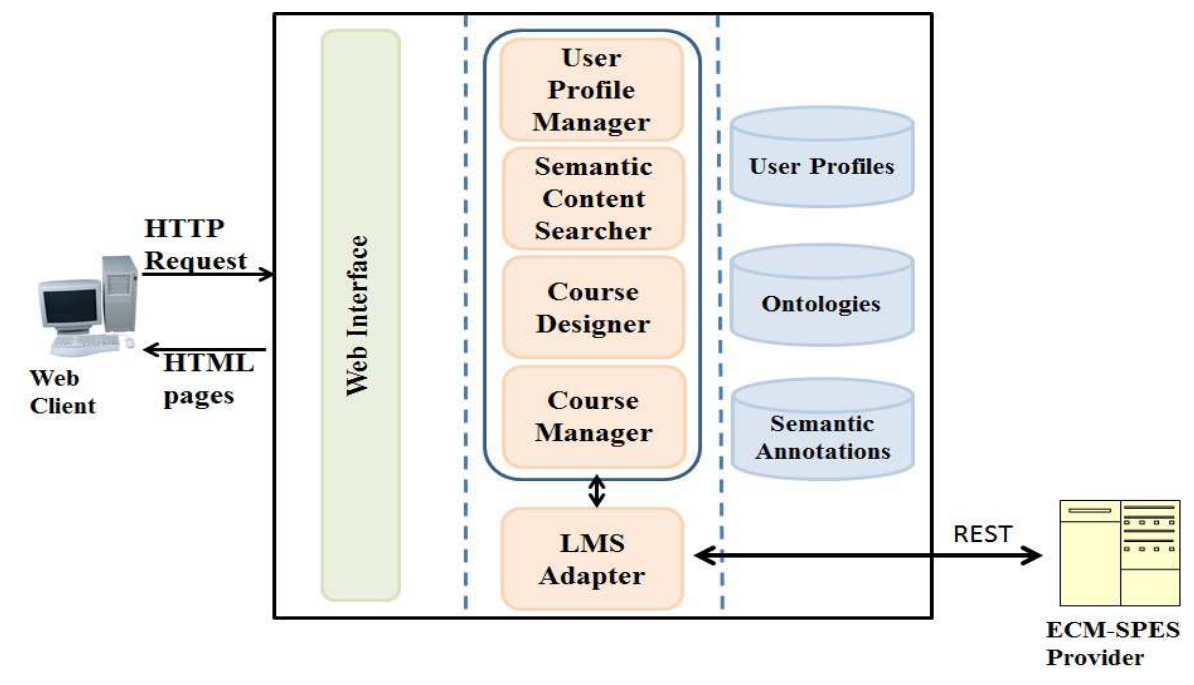

Fig. 6: The ELSE Architecture

The Semantic Content Searcher and the Course Designer modules implement the novel aspects of the approach, although the novelty of the proposal is given by the integration and the interaction of all the presented modules. The Semantic Content Searcher is, in particular, the module based on SemSim. On the basis of the semantic annotations, as mentioned before, it identifies the teaching material (the annotated RLOs) for the construction of the courses. It 
interacts with the Course Designer module, which is devoted to customizing the selected RLOs according to the user learning preferences. On the basis of the learning profile stored in the User Profiles repository, the Course Designer module organizes the RLOs selected by the Semantic Content Searcher and proposes the contents of the courses in a personalized way.

The Course Manager allows the association of the courses with the users, and interacts with the User Profile Manager for their update. It also interacts with the LMS Adapter for the generation of the courses on the ECM-SPES platform.

With regard to the implementation, the ECM-SPES platform stores the repositories containing the user data and the educational resources. The ECM-SPES Learning Management System is based on MOODLE v2.7 [5]. MOODLE (Modular Object-Oriented Dynamic Learning Environment) is a learning platform designed to provide administrators, educators, and learners with a single secure, robust, and integrated system to create personalized learning environments. The current version is based on a SOA architecture that allows MOODLE to communicate with other remote systems. In ELSE, the communication with the built-in MOODLE web service features is based on the REST (Representational State Transfer) technology [25]. It attempts to minimize response times and network communication while at the same time maximizing the independence and scalability of component implementations. A REST service is platform and language programming independent, and based on standard communication protocols (HTTP).

The RLOs are compatible with SCORM (Shareable Content Object Reference Model) [26]. They have been designed and developed with Xerte, an e-learning open source editor, developed by the University of Nottingham (UK) [27], for the creation of multimedial interactive, SCORM compliant, learning objects.

ELSE has been developed by using the Google Toolkit (GWT), and the application server for the system deployment is Apache Tomcat, which supports JavaServer Pages and Servlets.

\section{VALIDATION AND EXPERIMENTAL RESULTS}

The validation and the experimental results about ELSE are briefly summarized below. In the experiment, 13 representatives of health professionals were selected, in order to cover different professional categories: 2 family doctors, 3 nurses, 4 physiotherapists, 1 dietician, 2 laboratory technicians, 1 dental surgeon. They were previously contacted by the project staff in order to provide all their personal information necessary for the ECM Program. This information was stored in the MOODLE platform, and used by the ECM-SPES provider to define the credentials (login and password) for the access to the ELSE system. Before starting the experimentation, the users received a letter via email containing their credentials and some brief instructions about the participation in the experiment. In the letter there was also the link to an online questionnaire developed by the project staff to gather feedbacks about the experiment. The questionnaire, created with LimeSurvey [28], included two sections aimed at evaluating the effectiveness of the system about: (A) usability, (B) customization, and a third section, (C), devoted to an overall judgment about the course, the experiment, and the system. The usability was related to the instructions, the training material, and the integration of MOODLE with ELSE. The customization section concerned the usefulness of introducing the learning profile, and the distinction of the material according to theory, practice, etc. The overall judgment section, finally, was aimed at the formulation of an assessment about the course, the experiment, and the system, followed by the possibility of specifying a list of strengths and weaknesses of the system. The collected data show that the system has been found, in general, clear and usable. There is also a definitely positive consensus about the need of customization based on the learning preferences (100\% of responses), and about the usefulness of distinguishing among 
the different types of materials, i.e., theory, exercise, etc. The overall judgment about the experiment and the system was very positive (an average of 4.23 points out of 5).

\section{CONCLUSION AND FUTURE WORK}

The integration of semantic web methodologies and e-learning technologies is a challenge that has attracted a lot of attention over the recent decade [29]. In this paper the ELSE system has been presented, for the construction of ECM e-learning courses. It is ontology-based and integrates semantic search methodologies and e-learning technologies. The system has been tested in the domain of osteoporosis, and the overall judgment about it is very positive both in terms of usability and effectiveness of customization.

Currently, the English release of the prototype is being implemented and a deeper understanding of the learning outcomes, as defined according to the Tuning Project [23], is being investigated. In particular, we are expanding the component of the system related to the list of competencies and skills that the users are expected to achieve at the end of a learning process, which is an aspect that seems very interesting within the medical context.

\section{REFERENCES (TRANSLATED AND TRASLITERATED)}

[1] C. Peck, M. McCall, B. McLaren, T. Rotem, Continuing medical education and continuing professional development: International comparisons; British Medical Journal 320 (7232), pp. 432-435, 2000.

[2] A. Barbagallo, A. Formica, ELSE: an ontology-based system integrating semantic search and e-learning technologies; Interactive Learning Environments (ILE), 25 (5), pp. 650-666, 2017.

[3] ELSE. [Online]. Available: http://www.ecm-semantico.iasi.cnr.it

[4] SPES. [Online]. Available: http://www.ecm.formazione-spes.it

[5] MOODLE. [Online]. Available: http://www.moodle.org

[6] M. N. Asim, M. Wasim, U.G. Khan, W. Mahmood, H. M. Abbasi, A survey of ontology learning techniques and applications. Database, doi:10.1093/database/bay101, 2018.

[7] M. J. Somodevilla García, D. Vilarino Ayala, I. H. Pineda Torres, An Overview on Ontology Learning Tasks. Computacion y Sistemas, 22(1), 2018.

[8] A. De Nicola, A. Formica, M. Missikoff, E. Pourabbas, F. Taglino, A Comparative Assessment of Ontology Weighting Methods in Semantic Similarity Search; To appear in 11Int. Conf. on Agents and Artificial Intelligence (ICAART), Prague, 19-21 February, 2019.

[9] A. Formica, M. Missikoff, E. Pourabbas, F. Taglino, Semantic search for matching user requests with profiled enterprises; Computers in Industry 64(3), pp. 191-202, 2013.

[10] A. Formica, Concept similarity by evaluating Information Contents and Feature Vectors: a combined approach; Communications of the ACM (CACM) 52(3), pp. 145-149, 2009.

[11] J. K. Tarus, Z. Niu, G. Mustafa, Knowledge-based recommendation: a review of ontology-based recommender systems for e-learning. Artif. Intell. Rev. 50(1), pp. 21-48, 2018.

[12] E. D’Avanzo, T. Kuflik, M. D. Lytras, Building and using domain ontologies for learning in various domains: a semantic web-based learning perspective; IJKL 4(4), pp. 329-348, 2008.

[13] G. Angelova, O. Kalaydjiev, A. Strupchanska, Domain Ontology as a Resource Providing Adaptivity in eLearning; On the Move to Meaningful Internet Systems 2004: OTM 2004 Workshops, LNCS Vol. 3292, pp. 700-712, 2004.

[14] N. Henze, P. Dolog, W. Nejdl, Reasoning and Ontologies for Personalized E-Learning in the Semantic Web; Educational Technology \& Society (ETS) 7(4), pp. 2-97, 2004.

[15] M. Á. Sicilia, M. D. Lytras, S. Sanchez-Alonso, E. Garcia-Barriocanal, M. Zapata-Ros, Modeling instructional-design theories with ontologies: Using methods to check, generate and search learning designs; Computers in Human Behavior 27(4), pp. 1389-1398, 2011.

[16] C. Beeri, A. Formica, M. Missikoff, Inheritance hierarchy design in object-oriented databases; Data \& knowledge engineering 30 (3), pp. 191-216, 1999.

[17] A. Formica, M. Missikoff, Inheritance processing and conflicts in structural generalization hierarchies ACM Computing Surveys (CSUR) 36 (3), pp. 263-290, 2004.

[18] D. Lin, An Information-Theoretic Definition of Similarity; Proc. of Int. Conference on Machine Learning (ICML), Madison, Wisconson, USA, July 24-27, Morgan Kaufmann, pp. 296-304, 1998. 
[19] A. De Nicola, R. Navigli, M. Missikoff, A software engineering approach to ontology building, Information Systems 34 (2), pp. 258-275, 2009.

[20] ALCHEMY. [Online]. Available: http://www.alchemyapi.com

[21] S. Alvino, S. Bocconi, P. Boytchev, J. Earp, L. Sarti, An ontology-based approach for sharing digital resources in Teacher Education; Proc. of the Seventh Int. Workshop on Ontologies and Semantic Web for ELearning (SWEL), Brighton, UK, 2009.

[22] Share.TEC. [Online]. Available: http://portal.share-tec.eu

[23] Tuning. [Online]. Available: http://www.tuning-medicine.com

[24] R. M. Felder, L. K. Silverman, Learning and Teaching Styles in Engineering Education; Engr. Education 78(7), 1988

[25] R. T. Fielding, R. N. Taylor, Principled design of the modern Web architecture; ICSE pp. 407-416, 2000.

[26] SCORM. [Online]. Available: http://www.adlnet.org/scorm/

[27] XERTE. [Online]. Available: http://www.nottingham.ac.uk/xerte/

[28] Lime. [Online]. Available: http://www.limesurvey.org/en/

[29] M. Vargas-Vera, M. D. Lytras, Exploiting semantic web and ontologies for personalised learning services: towards semantic web-enabled learning portals for real learning experiences; IJKL 4(1), pp.1-17, 2008.

Text of the article was accepted by Editorial Team 11.11.19

\title{
ІНТЕГРУВАННЯ СЕМАНТИЧНОГО ПОШУКУ В ЕЛЕКТРОННІ ТЕХНОЛОГІЇ НАВЧАННЯ: СИСТЕМА ЕLSE
}

\author{
Анна Форміка \\ доктор, науковий співробітник \\ Інститут системного аналізу та інформаційних технологій "Антоніо Руберто" (IASI), Національна \\ дослідницька рада (CNR), м. Рим, Італія \\ ORCID 0000-0002-7992-6898 \\ anna.formica@iasi.cnr.it

\section{Алессія Барбагалло} \\ доктор, науковий співробітник \\ Інститут системного аналізу та інформаційних технологій "Антоніо Руберто" (IASI), Національна \\ дослідницька рада (CNR), м. Рим, Італія \\ alessia.barbagallo@iasi.cnr.it
}

\begin{abstract}
Анотація. Інтеграція семантичних вебметодологій i технологій електронного навчання $\epsilon$ проблемою, яка привертає велику увагу протягом десятиліть. 3 огляду на це, метою даної статті є визначення нової семантичної вебметодології електронного навчання для розробки курсів як дистанційної, так і очної форм навчання для медичних працівників. ELSE - це система, заснована на онтологіях, яка дозволяє створювати індивідуальні курси електронного навчання відповідно до потреб і вподобань. Вона об'єднує методології семантичного пошуку і технології електронного навчання. В основі методології лежить еталонна онтологія предметної області та навчальні мультимедійні інтерактивні модулі, звані як Багаторазово Використовувані Навчальні Об'єкти (МІУО) (Reusable Learning Objects (RLOs), які анотують відповідно до концепцій онтології. Користувач може вказати свої потреби в навчанні, вибравши набір понять 3 онтології, після цього механізм семантичного пошуку SemSim ідентифікує зазначені МІУО в такий спосіб, щоб найбільш ефективно задовольнити запит. SemSim - це метод семантичної подібності, який був використаний у численних експериментах. Він демонструє більш високу кореляцію суджень людини щодо найбільш значущих методів подібності, визначених у літературі. Набір МІУО послідовно реорганізується відповідно до власних уподобань у навчанні. ELSE був розроблений у рамках проєкту програми CME (Continuing Medical Education Безперервна медична освіта) - ЕСМ для італійських учасників - метою якої є впровадження нових методологій і інструментів у сфері підвищення кваліфікації медичних працівників і фахівців, що в подальшому забезпечить ефективність, безпеку і успішність національної служби охорони здоров'я.

ELSE була протестована і затверджена стосовно остеопорозу. Системі була дана позитивна оцінка як $з$ точки зору зручності використання, так і ефективності налаштувань. Система
\end{abstract}


ELSE розроблена в співпраці з постачальником послуг ECM SPES S.c.p.А., акредитованим Міністерством охорони здоров'я Італії.

Ключові слова: електронне навчання; профіль навчання; багаторазово використовуваний навчальний об'єкт; семантичний пошук; онтологія предметної області; семантична анотація.

\title{
ИНТЕГРИРОВАНИЕ СЕМАНТИЧЕСКОГО ПОИСКА В ЭЛЕКТРОННЫЕ ТЕХНОЛОГИИ ОБУЧЕНИЯ: СИСТЕМА ЕLSE
}

\author{
Анна Формика \\ доктор, научный сотрудник \\ Институт системного анализа и информационных технологий "Антонио Руберти" (IASI), Национальный \\ исследовательский совет (CNR), г. Рим, Италия \\ ORCID 0000-0002-7992-6898 \\ anna.formica@iasi.cnr.it
}

Алессия Барбагалло

доктор, научный сотрудник

Институт системного анализа и информационных технологий "Антонио Руберти" (IASI), Национальный исследовательский совет (CNR), г. Рим, Италия

alessia.barbagallo@iasi.cnr.it

\begin{abstract}
Аннотация. Интеграция семантических веб-методологий и технологий электронного обучения является проблемой, которая привлекает большое внимание на протяжении десятилетий. Учитывая это, целью данной статьи является определение новой семантической веб-методологии электронного обучения для разработки курсов как дистанционной, так и очной форм обучения для медицинских работников. ELSE - это система, основанная на онтологиях, которая позволяет создавать индивидуальные курсы электронного обучения в соответствии с потребностями и предпочтениями пользователя. Она объединяет методологии семантического поиска и технологии электронного обучения. В основе методологии лежит эталонная онтология предметной области и обучающие мультимедийные интерактивные модули, называемые как Многократно Используемые Учебные Объекты (МИУО) (Reusable Learning Objects (RLOs), которые аннотируются в соответствии с концепциями онтологии. Пользователь может указать свои потребности в обучении, выбрав набор понятий из онтологии, после этого механизм семантического поиска SemSim идентифицирует указанные МИУО таким образом, чтобы наиболее эффективно удовлетворить запрос. SemSim - это метод семантического сходства, который был использован в многочисленных экспериментах. Он демонстрирует более высокую корреляцию суждений человека относительно наиболее значимых методов сходства, определенных в литературе. Набор МИУО последовательно реорганизуется в соответствии с предпочтениями пользователя в обучении. ELSE был разработан в рамках проекта программы CME (Continuing Medical Education - Непрерывное медицинское образование) ЕСМ для итальянских участников - целью которой является внедрение новых методологий и инструментов в сфере повышения квалификации медицинских работников и специалистов, что в дальнейшем обеспечит эффективность, безопасность и успешность национальной службы здравоохранения.

ELSE была протестирована и утверждена в области остеопороза. Системе была дана положительная оценка как с точки зрения удобства использования, так и эффективности настройки. Система ELSE разработана в сотрудничестве с поставщиком услуг ECM SPES S.c.p.А., аккредитованным Министерством здравоохранения Италии.
\end{abstract}

Ключевые слова: электронное обучение; профиль обучения; многократно используемый учебный объект; семантический поиск; онтология предметной области; семантическая аннотация.

\section{(c) BY-NC-SA}

This work is licensed under Creative Commons Attribution-NonCommercial-ShareAlike 4.0 International License. 